\title{
Acleris lorquiniana (Lepidoptera: Tortricidae), in Central Italy
}

\author{
M. Pinzari, ${ }^{1}$ M. Pinzari ${ }^{2}$ \\ 'Dipartimento di Biologia, Università di Roma Tor Vergata; ${ }^{2}$ DIMI, Università di Roma 3, Roma, Italy
}

\begin{abstract}
Acleris lorquiniana (Duponchel, 1835) is a Palaearctic species that is known from Central and Northern Europe. This species was mentioned as occurring in Italy, but no precise collecting data were provided. The presence of Marsh button, $A$. lorquiniana, in Italy is confirmed by a single specimen collected in Central Italy that is identified by both external habitus and a dissection of the genitalia.
\end{abstract}

\section{Introduction}

Acleris lorquiniana (Duponchel, 1835) is a Palaearctic species that is known from Central and Northern Europe (Karsholt \& Nieukerken, 2011). Previously unrecorded in Italy (Razowski, 1984, 2002; Trematerra, 2003; Karsholt \& Nieukerken, 2011), its presence there was mentioned by Razowski (2008) in his book on Palaearctic Tortricidae.

A. lorquiniana is monophagous; the larvae feed on Lythrum salicaria L. (purple loosestrife) between spun leaves of young shoots, flowers, and seeds. The caterpillars pupate in debris on the ground. Adults overwinter and fly in two (rarely three) generations per year: in June and

Correspondence: Manuela Pinzari, Dipartimento di Biologia, Università di Roma Tor Vergata, Via della Ricerca Scientifica 1, 00133 Roma, Italy.

E-mail: manuela.pinzari@uniroma2.it

Key words: Acleris lorquiniana, Marsh button, Tortricidae, Lythrum salicaria, Italy.

Acknowledgments: the authors would like to thank Prof. Razowski, Institute of Systematics and Evolution of Animals PAS (Poland), for his help, and Prof. Trematerra, Università degli Studi del Molise (Italy), for his useful remarks and observations.

Received for publication: 5 November 2012.

Revision received: 6 December 2012.

Accepted for publication: 21 December 2012.

() Copyright M. Pinzari and M. Pinzari, 2013

Licensee PAGEPress, Italy

Journal of Entomological and Acarological Research 2013; 45:e3

doi:10.4081/jear.2013.e3

This article is distributed under the terms of the Creative Commons Attribution Noncommercial License (by-nc 3.0) which permits any noncommercial use, distribution, and reproduction in any medium, provided the original author(s) and source are credited.
July, and again from September to April (Razowski, 2002). Adults of $A$. lorquiniana are active at dusk, and they occasionally are attracted to light at night (De Prins \& Steeman, 2010). The host plant, L. salicaria, is an herbaceous perennial that usually grows in the water of rivers and canals. This plant is native to Europe and Asia, but it has become a weedy invasive in marshes and alluvial wetlands in all continents, especially in the north-eastern and north central United States (Batra, 1986; Blossey, 2001). In Italy, L. salicaria is widespread and can be easily found in wet meadows, on the edges of ponds and lakes, and on the banks of ditches.

\section{Materials and methods}

A single male of A. lorquiniana was collected by Mario Pinzari on 25 July 2008 at Sorgenti del Peschiera near Castel Sant'Angelo (Rieti) in Central Italy. The specimen was attracted to a 160-W Mixed Light lamp. Sorgenti del Peschiera is located in the plain of San Vittorino (400-420 $\mathrm{m}$ a.s.l.), an area rich in springs, creeks and lakes affected by subsidence (sinkholes) and bubbling phenomena, and also a source of sulphurous water. This is the typical native habitat of $L$. salicaria.

The moth species was identified by both external habitus and a dissection of the genitalia using the taxonomic characters reported by Razowski (2002). Genital parts were mounted on a microscope slide (Figure 1A). The specimen is deposited in the private collection of Mario Pinzari (Rome, Italy).

A. lorquiniana has a distinctive narrow forewing with an acutely angled apex and a brownish general colouration (Figure 1B). This species is variable, but usually shows a distinctive darker discal spot. It cannot be confused with any other species (Razowski, 2002). In addition to the external habitus, this species can be easily recognized by features of the genitalia. In the male genitalia, the socii are broadest basally, with a long, proximal base; the ventral edge of the basal half of the sacculus is rather straight, then concave, and shows a short and broad termination that is furnished with spines (Figure 1A). Moreover, the aedeagus is slender and has five long and thin cornuti in the vesica.

\section{Discussion and conclusions}

The singleton recorded in 2008 at Sorgenti del Peschiera confirms the presence of $A$. lorquiniana in Italy. In order to record more data about this species in the sampling area, we looked for moth specimens at dusk by sweep netting L. salicaria during July, August and September 2012. However, this search was unsuccessful, both in the locality of Sorgenti del Peschiera and in the areas in the plain around Rieti and the riversides of Velino. These findings suggest that $A$. lorquiniana is a rare species in Italy. 


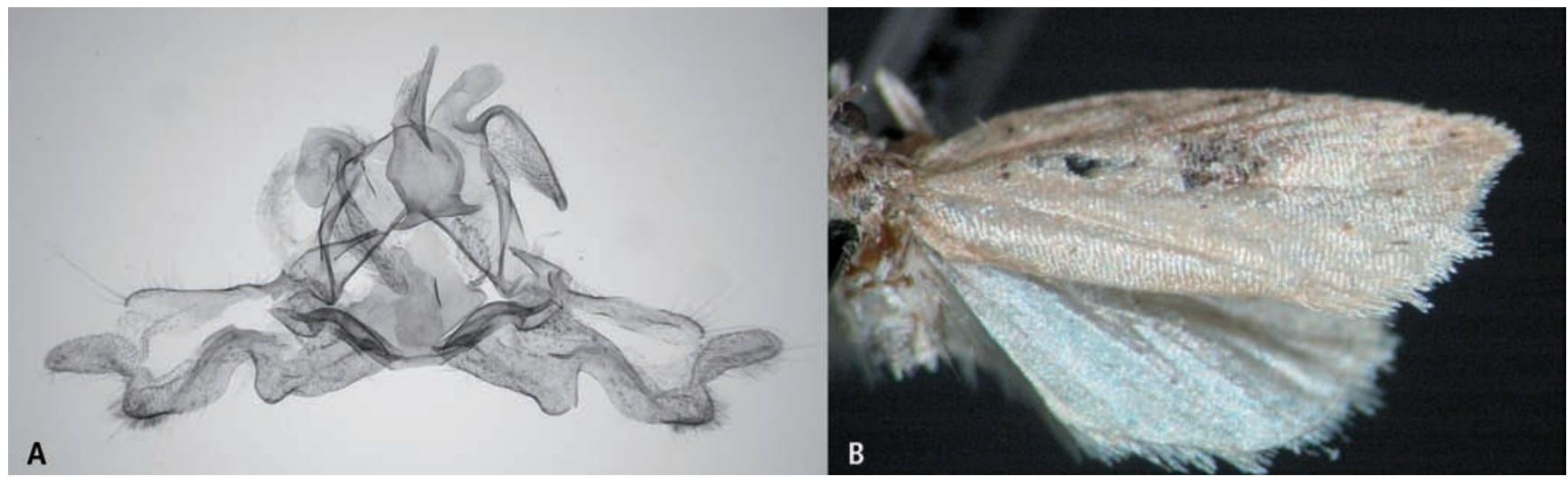

Figure 1. Acleris lorquiniana (Duponchel, 1835): male genitalia (A) and adult (B) (PREPT 1277, Manuela Pinzari).

\section{References}

BATRA S.W.T., SCHOEDER D., BOLDT P.E., MENDL W., 1986 - Insects associated with purple loosestrife (Lythrum salicaria L.) in Europe. - Proc. Entomol. Soc. Wash. 88: 748-759.

BLOSSEY B., SKINNER L.C., TAYLOR J., 2001 - Impact and management of purple loosestrife (Lythrum salicaria) in North America. Biodivers. Conserv. 10: 1787-1807.

DE PRINS W., STEEMAN C., 2010 - Catalogue of the Lepidoptera of Belgium. - Available from: http:/webh01.ua.ac.be/vve/Checklists/ Lepidoptera/LepMain.htm

KARSHOLT 0., NIEUKERKEN VAN E.J., 2011 - Lepidoptera. Fauna
Europaea Web Service, version 2.4. - Available from: http://www. faunaeur.org

RAZOWSKI J., 1984 - Tortricini. In: AMSEL H.G., GREGOR F., REISSER H., ROESLER R.U., Microlepidoptera Palaearctica, Band 6. - G. Braun, Karlsruhe: 1-376.

RAZOWSKI J., 2002 - Tortricidae of Europe, 1. Tortricinae and Chlidanotinae. - Frantisek Slamka, Bratislava: 247 pp.

RAZOWSKI J., 2008. Tortricidae of the Palaearctic Region, Vol. 1. Tortricini and General Part. - Frantisek Slamka, Bratislava: 69-70.

TREMATERRA P., 2003. - Catalogo dei Lepidoptera Tortricidae della fauna italiana: geonemia, distribuzione in Italia, note biologiche, identificazione. - Boll. Zool. Agr. Bachicolt. 35: 1-270. 